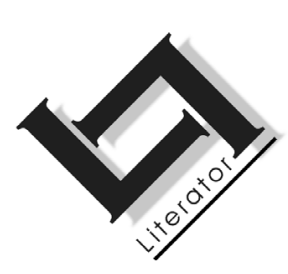

\title{
Songs about Zuma: revelations of divisions after democracy
}

\author{
M. Groenewald \\ Department of African Languages \\ University of Johannesburg \\ JOHANNESBURG \\ E-mail: hcgroenewald@uj.ac.za
}

Abstract

\section{Songs about Zuma: revelations of divisions after democracy}

In February 2006, when he was Deputy President of the country, Mr Jacob Gedleyihlekisa Zuma appeared in the Supreme Court in Johannesburg to defend himself against charges of rape. The charge of rape by a woman known only as Khwezi against a powerful politician, popular with many trade unions and many ordinary folk, not only gave rise to one of the major media events in that year in South Africa, but also revealed divisions in society and in politics. While Zuma supporters sang in his defence and to his praise, activists against women abuse criticised Zuma. On the one hand, the supporters of Zuma defended him with reference to his moral integrity; they also stated that he was the popular choice for future president, while they ridiculed the futile actions of his enemies. On the other hand, the activists against women abuse attempted to highlight Zuma's behaviour as immoral and urged women to speak out against abuse. This opposition revealed new divisions in society at large, as will be shown in the analysis of the songs.

\section{Opsomming}

Liedjies oor Zuma: openbaring van skeidslyne na demokrasie

In Februarie 2006, terwyl mnr. Jacob Gedleyihlekisa Zuma Visepresident van die land was, het hy in die Hooggeregshof in Johannesburg verskyn om homself te verdedig teen 'n aanklag van verkragting. Die aanklag, aanhangig gemaak deur 'n vrou, slegs bekend as Kwezi, teen 'n sterk politikus, gewild by 'n groot aantal vakbonde en gewone landsburgers, het aanleiding gegee tot een van die grootste mediagebeurtenisse van daardie 
jaar en belangriker nog, het nuwe skeidslyne binne die bevolking en in die politiek aan die lig gebring. Terwyl Zuma-ondersteuners hom in hulle liedjies verdedig en prys, het aktiviste van geweld teen vroue Zuma in hulle liedjies gekritiseer. Aan die een kant het Zuma-ondersteuners sy morele integriteit voorgehou, dat hy die populêre keuse is as toekomstige president, en dat die pogings van sy vyande tevergeefs is. Aan die ander kant het die aktiviste van geweld teen vroue Zuma beskuldig van immorele gedrag en mishandeldes aangepor om hulleself hoorbaar te maak oor seksuele misdrywe. Hierdie tweestryd was die spits van nuwe skeidslyne in die gemeenskap, soos bewoord in die liedjies wat behandel word.

\section{Introduction}

During February and March 2006, Mr Jacob Gedleyihlekisa Zuma appeared as the accused in a rape charge in the Supreme Court in Johannesburg. Following this accusation he resigned as Deputy President of South Africa. All the facts and incidents surrounding this case transformed it into an intriguing spectacle, including the mention of baby oil, and the burning of photographs and g-strings by the crowds outside the court, but most significant of all was the singing of protest songs by groups who were at enmity with one another. Clearly, these ingredients provided for a spicy cocktail of oral art. The "Zuma theatre", as one commentator called it (Hughes, 2006), also raised fears about the wellbeing of the democracy in South Africa. Four years later the rape incident hardly features in protest songs and in politics. The purpose of this article is to show how oral art, especially songs, not only captured opposing views at the time, but revealed different divisions in society after the advent of the new democracy.

\section{The context}

Being a prominent political figure, the appearances of Jacob Zuma at courts in Durban and Johannesburg on charges of corruption and rape respectively, generated enormous media attention. Adding to the significance of these events is his popularity, both within the ANC ranks and with the man in the street, who were incensed about the accusations against Zuma. People voiced their opinions in no uncertain terms in strongly worded political songs. This drama gave rise to a multi-facetted tension between various groups: while the major stand-off was between the law and the Zuma camp, conflict heightened between certain ANC factions, particularly between the Youth League, who came out in support for Zuma, and the pro- 
Mbeki group. Another major divide at the time of the court cases was between activists against women abuse on the one hand, and the people who supported Zuma on the other. Although the media is in principle impartial, there is no doubt that their presence - especially that of television reporters - heightened the level of fervour of the performing groups in the sense that the moment the cameras were on a certain group, that group would perform with more vigour. Not to be forgotten were certain performing artists who fuelled the tension with their songs. In short, the Zuma theatre was a captivating social spectacle which revealed, through songs, T-shirts and placard politics, ominous splits in postapartheid democracy.

\section{Performativity and political songs}

Performance, or performativity, as some scholars prefer to refer to creative performance (as opposed to ritual), is about asserting a presence in order to achieve a desired result. The efficacy of performance lies in collective group synergy, characterised by common intent, commitment and energy. Hughes-Freeland (1998:6) describes the intentionality in performance as deliberateness.
A performance is not necessarily more meaningful than other events in one's life, but is more deliberately so; a performance is, among other things, a deliberate effort to represent, to say something about something.

Conscious collective intent is not only the creative energy leading to a performance, but is also linked to the purpose of a performance people perform to achieve an outcome. In order for a performance to achieve its outcome it must have an expressive dimension. Performers normally do not rely on presence alone to achieve a result; they achieve results by their utterances and actions. The importance of expressiveness in political performances is clearly seen in the manner in which political songs are performed. Singers invariably regard volume and much physical action as an effective means of projecting the message. In Africa performance efficacy and entertainment are not mutually exclusive. Getting a message across does not exclude the enjoyment of a song. The immediate success of a performance can be measured by the number of performers it draws from the onlookers. It achieves this success through the demonstration of the enjoyment of the performance. Clearly, this type of deliberate action has the potential to create tension and division, especially in a group or groups who may be averse to the sentiments expressed by the opposing group. 
Democracy in South Africa was achieved through mass mobilisation, "by the sustained insurgency of lower-class actors" (Wood, 2000:5). The political song has played a major part in achieving democracy in South Africa, but in my view, oral art as "literature from below" - in this case in the form of the struggle song - was the fuel for this mobilisation. Songs sung by supporters of Zuma were a continuation of the tradition of the singing of struggle songs. In Zuma's case the performers were trying to strengthen his position by illustrating in song that he had popular support.

\section{The function of struggle songs}

In the resistance years (up to 1994) struggle songs were often sung as instruments of resistance against the apartheid government. After 1994, although democracy had been achieved, the singing of political songs has not diminished. In fact, the scope of intent of struggle songs has broadened in postapartheid South Africa. The same songs that were sung to assist in the demise of apartheid are now sung in celebration, for example, as was the case at the celebration of ten years of democracy at the Union Buildings in 2004. Another objective of struggle songs would be to criticise the government about service delivery, as was evident in the run-up to the elections for local government in 2005 and in the run-up to the general election in 2009. Within the focus of the present article, one can further note that the singing of struggle songs at the court appearances of Zuma was to express popular ideas and popular support for Zuma. The songs expressed support for Zuma as future president of the country; they challenged the judiciary and they were also used to intimidate the accuser and her supporters in the Zuma rape trial. On the other hand, the singing of struggle songs for the alleged rape victim was meant to establish a presence for women's rights and to condemn the abuse of women. The Zuma trials can also serve as a reference point to illustrate how struggle songs have evolved as a genre. One reporter referred to the singing at the court as "traditional Zulu songs" (Smillie, 2006a). This is not entirely correct. Traditional Zulu songs, one would assume, are the songs typically sung at Zulu ceremonies and their content often relates to the particular ceremony. For instance, at Shaka Day ceremonies the war cries (iziqubulo) refer to aspects of preparing for and engaging in battle, and royal battle songs (amahubo) are songs that refer to specific Zulu kings. The songs referred to in this article are clearly struggle songs or political songs in that they refer to political figures, the suffering of people, and so on. Struggle songs have been adapted from socalled traditional songs as well as from church songs, while many 
others are original struggle songs, in other words, songs that have originated in the context of engagement with political rivals.

The performances at the Supreme Court in Johannesburg, have, as mentioned before, been labelled in theatrical terms, showing how commentators have tried to come to terms with these events. While one commentator has spoken of the "Zuma theatre", another has spoken of an "elaborate pantomime". Following MacAloon (1984), one can say that events that fall within the spectrum of ritual to creative performance are varieties of the following: rite, drama, festival, and spectacle. The performances at the Supreme Court can be termed expressive spectacles, where performers perform outrageously to impress spectators and to express their views.

\section{Opposing performers in the Zuma trial arena}

The performance arenas, for the purposes of this article, were the streets opposite the main entrance of the Supreme Court in downtown Johannesburg. The supporters of the alleged victim consisted mainly of women and they confined themselves to a corner of the Supreme Court block (corner of Pritchard and Von Wielligh Streets). Zuma supporters, on the other hand, moved over a wider area, and were even allowed at one stage by the police to approach the women's rights group in an attempt to intimidate them.

The performers and partakers in these spectacles can be placed in three main groups. The Zuma group was the most formidable and consisted of Zuma and his bodyguards, members of his family (some of whom wore traditional dress in court), his legal team, the Friends of Jacob Zuma (who established the Friends of Jacob Zuma Trust), and the masses of singing supporters. In support of Zuma were also some musicians, such as the group Izingane Zoma whose song "Msholozi" (a clan praise name for the Zuma clan) was played from a vehicle in front of the court. (This song was also played on the radio station Ukhozi FM, only to be withdrawn after complaints were received. People possibly objected to the fact that one specific political leader was being favoured by the radio station.) The CD $100 \%$ JZ (Mthethwa, s.a.), produced by musician and producer Mthethwa, came out some time before the trial in Johannesburg. Mthethwa dedicates the CD to Zuma in "moral support through these uneasy times that he is faced with". Mthethwa's belief in the moral integrity of Zuma (as contained in the words in Annexure A) was remarkably close to sentiments seen on placards during the rape trial. Some members of the police were also seen to be proZuma, as they were witnessed on one occasion helping Zuma sup- 
porters onto a police vehicle to gain a better vantage point. Behind the visible contingent of the Zuma group was an equally formidable base of sympathisers. Zuma himself (Zuma, 2006) acknowledged the support throughout the trial of the following organisations: members in the ANC, in the ANC Women's League, as well as in the South African National Civic Organisation (Sanco) and the SA Students Congress (Sasco). He singled out for special mention the SA Communist Party, Congress of SA Trade Unions (Cosatu), the ANC Youth League, the Young Communist League, Congress of SA Students (Cosas), the Progressive Youth Alliance, the Mkhonto Wesizwe Military Veterans Association and the Friends of Jacob Zuma Trust Fund. Zuma supporters put considerable effort into their backing. They organised vigils, a gala dinner and a concert and also set up a website (friendsofjz.co.za). All of these efforts were aimed at collecting funds to pay for his legal expenses. The ANC Youth League sponsored T-shirts, many of which carried the slogan " $100 \%$ Zulu Boy". The number of performers for the Zuma faction ranged from about 50 or less on certain occasions to thousands, depending on the stages the trial went through.

The antagonists so to speak, were the accuser, women's rights groups such as POWA (People Opposing Woman Abuse) as well as other activists, for instance the TAC (Treatment Action Campaign). These performers did not number more than about 100 at their performances. This group got sympathy from organisations such as the Tshwaranang Legal Advocacy Centre, the Centre for the Study of Violence and Reconciliation, the Centre for Applied Legal Studies, Men and Women Against Child Abuse, and the One in Nine Campaign.

Trying to occupy impartial ground were the tritagonists comprised of the judiciary, the police, journalists and researchers, the last being a small minority numbering perhaps two or three and exerting a miniscule influence over the performances. Excluding the researchers, the role of the tritagonists in this theatre was significant. The Zuma group and the women's rights group were very much aware of media coverage and were, to some degree, performing to be noticed by the media. Not only that: these opposing groups were each performing to sway the judiciary, if in any way possible, to their own preferred outcome of the trial. Some of the lyrics of the songs - see sections 6.7 and 6.8 later - of both the opposing groups show that the groups were informing the judiciary regarding who was possibly guilty or innocent. The police played the vital role of keeping the 
opposing groups apart, thus ensuring that their voices could be heard.

The main actors in these performances - the pro-Zuma singers and the women's rights group - highlighted a few oppositions. The majority pro-Zuma group was celebrating a leader and what they perceived he stood for despite the accusations against him. For this group the level of entertainment in their performances was as important as the efficacy of their performance. For the minority group, the women's rights performers, the performance was not about entertainment, but about having a voice in a country known for abuse of women. Furthermore, for them the perceived justice for the accuser at that time was at stake. And yet, these opposing groups often sang the same song, adapted to their own ideologies. In performance terms, the Zuma group was more deliberate, resulting in a greater measure of creativity and self-confidence than the women's rights group, whose singing was at times characterised by false starts and self-censure. The tritagonists did not partake in the singing of songs.

The songs used in this article come from the following sources: a performance at the University of Johannesburg in October 2005, performances at the Supreme Court of Johannesburg, recorded on 14/2/06 and 6/3/06, and from CD releases.

\section{6. "Cocktail of issues"}

The spectacles at the Supreme Court provided an interesting mix of topical and ideological issues. One academic has spoken of a "cocktail of issues" loaded into one case (Smillie, 2006b). In the following paragraphs the most important issues in contention in the songs of both the Zuma group and the activists for women's rights will be dealt with.

\subsection{The succession debate}

First and foremost among these issues was the rift between President Thabo Mbeki and Zuma. Some Zuma supporters reiterated the conspiracy theory, namely that Zuma was accused of rape so as to deal a blow to his chances of becoming president. The songs by performing artists as well as the performances by Zuma supporters confirmed that Zuma enjoyed considerable support, to the extent that Zuma supporters clearly favoured him to become president, as a few songs advocated: 
(Unless indicated otherwise, the songs that follow were recorded by the author of this article. Underlining represents the response. Double vowels represent significant length. Where significant substitute sections are given below the main text of the song. The letters $a, b$, et cetera, indicate stanzas. Note that call and response usually overlap, and that in some cases the call can be repeated over a considerable length of the response. In performance stanzas or lines are often repeated; but for the sake of space these repetitions are not always indicated in this article. The translations are dynamic equivalents as far as possible.)

\section{Examples}

1 Indaba kabani? Indaba kabani ma sifun' uZuma?

Whose concern is it? Whose concern is it if we prefer Zuma?

2a UZuma1 yo UZuma yo myy president

2b Oh myy president My president

Oh my president Myy president

3 O Zuma ngowethu Siyavuma

O ngowethu ngempela Siyavuma

Uzohlala eyipresidente Siyavuma

O siwele le ${ }^{2}$ siwele le siyavuma

Oh Zuma is one of us we agree

Oh he is one of us indeed we agree

He will remain president we agree

Oh siwele le siwele le we agree

The last example (3) is adapted from a wedding song.

The style and the detail in which the musical group Izingane Zoma expressed this issue in the song "Msholozi" (Izingane Zoma Music, 2005) was an indication of how strong the popular surge of support for Zuma was by 2005; note the direct voice in the last line. Men and women sing different parts in the song:

1 UZuma/UMsholozi (substitute, in other words, instead of UZuma also Umsholozi in subsequent versions of the song).

2 siwele le can be translated as "we have crossed over to there", but in this song these are probably meaningless syllables intended to fulfil a rhythmic function. 
Women: Bonk' abantu bathi bafun' uZum' aphathe

Men: AbenguNew South Afrika

Men: Abawaboni amacala agwetshwa ngawona

Women: Epalamende abavumi ukuth' uZuma abe nguhulumeni

Men: Kanti ngiyoba ngiyisekela kuze kube nini?

Women: All the people say they want Zuma to rule

Men: $\quad$ He must be the New South Africa

Men: They don't acknowledge the accusations he is accused of

Women: Those in Parliament don't want him to rule

Men: $\quad$ But for how long must I be Deputy?

To what did Zuma owe such support at the time? Many commentators ascribed his popularity to his style of communication, which was and still is often more accessible to working-class and rural people than the more intellectual style of the president at that time, Thabo Mbeki. As one writer said: "Zuma is a showman while Mbeki is a shy man who works effectively behind scenes." (Shange, 2006.) One song intimates that Zuma is in touch with povertystricken people. Note that the singers indicate that Zuma is popular both in rural areas (as expressed in the phrase "wen' osel' ekhaya" you who remain at home, i.e. rural area) and in the township (elokishi). The synonym "ekasi" for "elokishi" (both words mean township but ekasi is derived from the Afrikaans lokasie, while elokishi is derived from the English location) may have been used by the singers simply for rhythmic purposes, but it would not be far-fetched to load it with ideological intent: since the word ekasi has a value of endearment, the singers seem to be indicating that Zuma would be more intimately involved with people where they live:

a Ucomrade uZuma angangibona nginje angalaleee ${ }^{3}$ Angalalela uma sinje

b Hhayi angalaleee uma sinje

Hhayi angalaleee Angalalela uma sinje

c Sihamba noZuma Sihamba noZuma

Sihamba noMsholozi Sihamba noMsholozi

3 This word is the corrupt spelling of angalalela (he would heed/listen). 
d Wen' osel' ekhaya Wena' osel' ekhaya

Wen' osel' elokishi Wen' osel' ekasi

a If Comrade Zuma could see my state he would heed $\underline{\mathrm{He}}$ would heed us in our state

b Yes he would heed us in our state

Yes he would heed us He would heed us in our state

c We go along with Zuma We go along with Zuma

We go along with Msholozi We go along with Msholozi

d You who stay at home You who stay at home

You who stay in the township You who stay 'ekasi'

However, one commentator has pinpointed the difference between President Mbeki and Zuma on demographics:

But the real contest is about something other than political style, race or ethnicity. I believe the divide runs along the urban-rural axis. For a party that has deep support in the country's remote rural areas the ANC's national leadership appears overwhelmingly urbanised. And no one represents urban more than Mbeki.

On the other hand, Zuma appears to have got into this mess in the first place as a result of the kind of costs associated with an expanding homestead [...], something rural Zulu men will recognise. [...] to many of them he's 'Mr Delivery'. (Schmidt, 2005.)

Although ethnicity and culture was not a crucial dividing factor in the succession issue, it was brought to the fore in some songs, through T-shirt and placard slogans, and by Zuma himself when he testified in court that it was against Zulu culture to leave a woman unsatisfied. The third stanza of a song contains the oft-heard phrase "Zulu boy":

Uban' uZulu boy, Zulu boy, uban' uZulu boy, ngiyabuz'?

Uban' uZulu boy, Zulu boy, uban' uZulu boy, ngiyabuz'?

Who is the Zulu boy, the Zulu boy, who is the Zulu boy, I ask you?

\subsection{Questionable populism}

An issue that was met with concern about the Zuma theatre related to the callousness exhibited by Zuma supporters to the rights of the 
victim during the trial, which quickly became a broader human rights issue. When Zuma supporters burned pictures and an effigy of the victim, and burned G-strings and condoms, and sang songs depicting the victim as a bitch, serious concern had to be raised about the morality and wisdom of the populace. These actions caught the attention of the Public Protector, the Gender Commission, as well as the SA Human Rights Commission, who condemned the burning of photographs and the insults directed at the alleged victim (Sapa, 2006).

\subsection{The spirit of defiance and militancy}

In accordance with the defiant attitude of their leader at the time, some of the songs of the Zuma group expressed a militant spirit, as is characteristic of struggle songs. In these songs singers often mention dangerous weapons. The example to start with is obviously Zuma's theme song:

Umshini wami umshini wam' Awuleth' umshini wam' awuleth' umshini wam' awuleth' umshini wam' awuleth' umshini wam'

My machine my machine Bring my machine, et cetera

In an article tracking the life of this song, Liz Gunner (2008:38) summarises the militant context of the song as follows:

The song, chosen by Zuma himself and brought (back) into circulation by him with ease and elegance, broke into popular public memory by recalling an earlier and more dangerous way of being. It evoked the years of pre-1994 resistance to the apartheid regime, the tense urban gatherings and the mass funerals.

In discourse about phallic symbols and in the context of the rape trial it would not be unfounded to suggest a semantic connection between umshini wami and the phallus.

Another example of militancy at this time comes from the October 2005 performance at the University of Johannesburg:

a Ibambeni we-zinsizwa, Ibambeni we-bafana

b Le zibhamu zala bafana zingikhumbuz' u-Oliva Tambo

a Take part in the battle young men, get into the battle you $\underline{\text { boys }}$

b The guns of these boys remind me of Oliver Tambo 


\section{Other examples:}
a Shona malanga Shooona
Shona malanga Shona malanga shona
b Sesizodibana dibana ngebhazuk' ehlathini

a Set sun $\underline{\text { Set}}$, et cetera

b We will meet, meet with a bazooka in the bush

a Wen' uZum' uth' ayihlome Wen' uth' ayihlome

b Wen' uth' ayihlom' ihlasele Wen' uthi ayihlom'. Siyaya ngomkhonto wesizwe. Wen' uth' ayihlome

a You, Zuma says let it take up arms You, he says let it take up arms

b You, he says let it take up arms and attack You, he says let it take up arms. We are going with the spear of the nation. You, he says take up arms

Some of these militant songs have come a long way and are used repeatedly in various contexts. Up to 1994 the revolutionary and defiant spirit palpable in these songs was directed against an undemocratic government; the same songs are now sung in a populist spirit challenging certain aspects of the democratic leadership.

The only song sung by the women's rights group that had a trace of strong action is the following song, which alludes to the fact that POWA has power:

a Ma iPOWA Ma iPOWA ibashayayo ibashayayo Wena Zuma Wena Zuma wel' olwandle wel' olwandle

b Ungakhali Ungakhali wena mama wena mama IPOW' ikhona IPOW' ikhona izobashaya izobashaya

c 'Zungakhali 'Zungakhali wena mama wena mama IPOW' ikhona IPOW' ikhona izobashaya izobashaya not occur in the song but which is always assumed by the singers. 
a When POWA When POWA strikes them strikes them

You Zuma You Zuma go overseas go overseas

b Don't cry Don't cry you woman you woman

POWA is here POWA is here it will strike them it will strike $\underline{\text { them }}$

c Don't cry Don't cry you woman you woman

POWA is here POWA is here it will strike them it will strike them

This song was not directed against leaders but at a generic group of women abusers. During the time of the rape trial, the women's rights group believed Zuma fell into that category. Unlike the examples mentioned above, the song does not have revolutionary undertones.

While Zuma supporters encouraged the spirit of militancy, women's rights groups urged their supporters to exercise their rights, for example to speak out:

a Khetha mfazi khetha! Khetha!

b Bua mfazi bua! Bua!

c Khuluma mfazi khuluma! Khuluma!

d Thetha mfazi thetha! Thetha!

e Speak out mfazi speak out! Speak out!

a Choose, woman, choose! Choose!

b Speak, woman, speak! Speak!

c Speak, woman, speak! Speak!

d Speak, woman, speak! Speak!

e Speak out, woman, speak out! Speak out!

Lines b, c, and d are sung in Northern Sotho, Zulu and Xhosa respectively; however, the Zulu/Xhosa word for woman is retained throughout the song.

\subsection{Leadership and following}

Both groups preferred a leader who had the credentials of a freedom fighter, as expressed in the metaphor inyamazane. This word simply means buck/antelope; it became the metaphor for freedom fighter, because, like an antelope, a freedom fighter lives/operates from the bush. The Zuma group mentioned Zuma as their freedom fighter: 
a Hhaayi nyamazan' Hhayi nyamazan'

Hhayi nyamazan' Hhaayi nyamazan'

b Msholozi yo Msholozi yo hhayi nyamazan'

c Myy president My president

My president Myy president

d UZuma yo UZuma yo my president

As mentioned before, performing artists have dedicated some songs to Zuma. The song "Akekho Ofana Nawe" performed by Mthethwa et al. (s.a.) contains a praise poem for Zuma, which cannot be dealt with in detail here, in which Zuma's credentials as freedom fighter are eulogised as follows:

Uqala ukuzabalaza ecreche, primary, high school, college, university

You started the struggle at crèche ...

This line illustrates how populist eulogy inflates a leader's credentials. (See also the annexure at the end of this article.)

The followers of Zuma are prepared to follow their leader no matter what the cost may be:

a UZuma wethu Somlandela UZuma wethu Somlandela

b Noma besibopha Somlandela Noma besibopha Somlandela

a Our Zuma We will follow him Our Zuma We will follow him

b Even if they arrest us We will follow him Even if they arrest us We will follow him

The popularity of Zuma is clearly illustrated by the following song in Xhosa. The Xhosa singers are prepared to align themselves with Zuma's ancestor to gain his favour:

a O ndoyiika ndoyiika Ndoyika ndoyika ndoyika uShaka

b O ndakhetha ubukhomanisi ndalahla ubukapitali ndoyik' uShaka Ndoyika uShaka

a Oh I fear I fear I fear I fear I fear Shaka

b Oh I chose communism and abandoned capitalism I fear Shaka I fear Shaka 
The following song raises another interesting aspect of Zuma's popularity, namely that he attracts a leftist following. In this song the singers express their rejection of the bourgeoisie:
a Jacob Zuma ngibambe ngesandla ngingayi kumabhujwa
b Inhliziyo kaZuma imnene sengizocasha kuyona
a Jacob Zuma hold my hand so I may not go to the bourgeoisie
b The heart of Zuma is kind and I will hide in it

In the next example the singers reject capitalism and hint at the conspiracy to discredit Zuma:
a I-agenda yamakapitali asiyifuni i-agenda yamakapitali asiyifuni
b Yamxosh' uZuma asiyifuni i-agenda yamakapitali asiyifuni
c Yambulal' uZuma asiyifuni i-agenda yamakapitali asiyifuni

a The agenda of the capitalists we don't want it the agenda of the capitalists we don't want it

b It drove Zuma out we don't want the agenda of the capitalists we don't want it

c It killed Zuma we don't want the agenda of the capitalists we don't want it

Although the women's rights group also preferred an activist as leader, they did not seek refuge with a political leader. They mentioned Kerry as their leader, referring to Kerry Shelver, who was the Training and Public Awareness Officer in POWA at the time and who organised the women's rights actions:
a O Keri ya yo Keri ya yo hhayi nyamazan'
b Hhaayi nyamazan' Hhayi nyamazan'
c Hhayi nyamazan' Hhaayi nyamazan'

a Oh Kerry ya yo Kerry ya yo oh yes the antelope

b Oh yes the antelope oh yes the antelope

c Oh yes the antelope oh yes the antelope 
The syllables ya yo are meaningless and are used by the singers for rhythmic purposes. Hhayi literally means no, but it is often used to express surprise and wonder, hence the translation oh yes.

Another example:
a We-nyamazan' Yiyo le ehlal' ehlathini
b Ihlal' ehlathini Yiyo le ehlal' ehlathini
c Halala we-nyamazan' Yiyo le ehlal' ehlathini

a Hey animal It is the thing that lives in the bush

Et cetera

The women's rights group claims a following on gender lines:
a Yonk' indawo abafazi bethu basisapota
Yonk' indawo abafazi bethu basisapota
b Le nale abafazi bethu basisapota
a All over our women are supporting us
Et cetera

In contrast to the strong political nature of songs of the Zuma supporters, the women's rights group adapted a religious song revering the name of the Lord to show their admiration for women and children in general. Instead of igama likaJesu (the name of Jesus) they sing of the "name of the women" (igama lamakhosikazi):

\section{Examples:}

1a Igama lamakhosikazi malibongwe

b Malibongwe malibongwe

a May the name of women be praised Et cetera

2a UJesu uphakeme Uphakeee Uphakeme Uphakeme Uphakeme Uphakeme uJesu uphakeme

b Igama leNkosi malibongwe Malibooo Malibongwe Malibongwe Malibongwe Malibongwe igama leNkosi

c Igama lezingane liphakeme Liphakeee Liphakeme 
Liphakeme Liphakeme Liphakeme igama lezingane

a Jesus is exulted $\mathrm{He}$ is exulted Et cetera

b May the name of the Lord be exulted May the name of

the Lord be exulted Et cetera

May the name of the children be exulted May the name

of the children be exulted Et cetera

\subsection{Poverty}

The following song illustrates that the unemployed and povertystricken populace were pinning their hopes on Zuma:

a Ucomrade uZuma angangibona nginje angalaleee Angalalela uma sinje

b Hhayi angalaleee uma sinje Hhayi angalaleee Angalalela uma sinje

c Sihamba noZuma Sihamba noZuma Sihamba noMsholozi Sihamba noMsholozi

d Wen' osel' ekhaya Wena' osel' ekhaya Wen' osel' elokishi Wen' osel' ekasi

See translation on p. 132.

\subsection{Suffering}

Whereas the followers of Zuma mentioned poverty and unemployment as their plight, the women's rights group sang about their suffering as oppressed women, which included the issue of seeing women as mere objects for sexual exploitation. The songs referred to the rape of men as well:

Examples:

Sithwele kanzima sithwele kanzima, sithwele kanzima yilabo baba

We suffer bitterly we suffer bitterly, we suffer bitterly under those men 
2a Wen' ulele laph' endlini wen' ulel' umis' amanqolo

b Nithini madoda yisimangaliso?

Sekudlengulw' amadoda

a You lie here in the house you lie backside up

b What do you say men, isn't it an astonishing thing?

Men are being raped

The use of vivid language in this song - vivid/direct/forceful/uncensored language is characteristic of most protest songs, regardless of who sings or may hear the song(s) - is meant to express the amazement of the singers, but more importantly, to capture the attention of listeners.

They see AIDS as one of their burdens, hinting that it comes as result of male domination:

a Sithwele kanzima, sithwele kanzima yile ngculazaa

b Sithwele kanzima yilabo baba yile ngculazaa

a We are suffering under those men, under Aids

b We are suffering under those men under Aids

The women's rights group sang the song Senzeni na? It is one of the oldest and most common struggle songs, with a slow rhythm and haunting tune. The women find the song appropriate to the dire circumstances under which they are living; the song simply asks "what have we done" (to deserve this)?:

a Senzeni na? Senzeni na, senzeni na?

b Senzeni na? Senzeni na, senzeni na?

\subsection{Enemies}

The Zuma group identified prominent people in law enforcement and in the ANC who it perceived to be against its cause. They admonished these people not to harass Zuma and they warned them that there would be (bad) consequences: 
a Labo bedlala 5 ngoZuma ngoZuma, labo bedlala ngoZuma bazoyidel' inkani

Labo bedlala ngoZuma ngoZuma, labo bedlala ngoZuma bazoyidel' inkani

b O lala Ngoepe, lala Ngoepe, o lala Ngoepe, o lala mawulele

O lala Ngoepe, lala Ngoepe, o lala Ngoepe, o lala mawulele

Ngoepe/Ngcuka,/Pikoli/Macozoma/Saki

a Those who play with Zuma will suffer the consequences of their obstinacy

Et cetera

b Back off Ngoepe, back off and lie down

Et cetera

c Uban' uZulu boy, Zulu boy, uban' uZulu boy, ngiyabuz'

Uban' uZulu boy, Zulu boy, uban' uZulu boy, ngiyabuz'

c Who is the Zulu boy, Zulu boy, who is Zulu boy, I ask you?

Et cetera

Another variant of this song mentioned other high-profile people, most of which were in law enforcement:

a Nabo bethinta noZuma aboZuma, nabo bethinta noZuma bazoyidel' inkani

Nabo bethinta noZuma aboZuma, nabo bethinta noZuma bazoyidel' inkani

Those who play with Zuma will suffer the consequences of their obstinacy

Et cetera

5 The incorrect grammar here is perhaps enforced by the rhythm; it should read

"labo abebedlala ..." or "labo ababedlala ...". 
b Naye uMakhosini Nkosi uhluph' uZuma naye uMakhosini Nkosi uzoyidel' inkani

Noma uMakhosini Nkosi hhay' uNkosi uMakhosini Nkosi uzoyidel' inkani

b He too, Makhosini Nkosi, is pestering Zuma, he too will suffer the consequences

Even Makhosini Nkosi, oh yes, Nkosi Makhosini Nkosi will suffer the consequences

c O lala o lala o lala Ngcuka we-Ngcuka o lala Ngcuka o lala mawulele

O lala Ngcuka lala Ngcuka o lala Ngcuka o lala $\underline{\text { mawulele }}$

Ngcuka/Saki Macozoma/Smuts Ngonyama/Mzi Khumalo/Ngoepe/jaji (judge)

c Oh lie down (= back off) Ngcuka, hey Ngcuka oh lie down Ngcuka, oh if you could lie down. Et cetera

d O lala o lala o lala o lala o lala Khayi hhayi we-nqulo o lala Khayi o lala mawulele

O lala Khayi lala Khayi o lala Khayi o lala mawulele

d The translation is the same as for c except for the word we-nqulo, which I could not find or clarify with mothertongue speakers - it may be an obscene word.

As in the previous section, the women's rights group identified an enemy on the grounds of gender, namely the men who have beaten, murdered and raped are the enemy:

a Ishaya kanjani? Ishaya kanjani?

b Idubula kanjani? Idubula kanjani?

c Ireypa kanjani? Ireypa kanjani?

a How it beats? How it beats?

b How it shoots? How it shoots?

c How it rapes? How it rapes? 
The subject marker I ("he"/"it") in the song undoubtedly refers to indoda "man". Although the question marks suggest that questions are being asked (kanjani "how"), the song expresses amazement.

\subsection{Morality and state of the country}

The following two examples illustrate how the Zuma group maintained that Zuma was righteous; they treated the accusation against him with great contempt:

1a Inhliziyoo yakaZuma ingcwele Sesizocasha kuyona

b UMsholozii UMsholozi Sesizomphatha ngezandla

a The heart of Zuma is holy we will hide in it

b Msholozi Msholozi we will carry him on our hands

2a Ushit Ushit Ushit Ushit Ushit Ushit ayikho le nto

b Wayinyomf' Wayinyomfa Wayinyomf' Wayinyomfa Wayinyomfa Wayinyomf' ayikho le nto

a It is shit, there is no truth in it. Et cetera

b You have confused the issue. Et cetera

Judging from the text of the following song, looking specifically at the tense of the verb (oyenzayo - "what you are doing"), the women's rights group did not condemn a specific action; they were criticising a certain lifestyle. It is interesting to note that they expressed this sentiment in Afrikaans as well, the language of the former oppressor:
a Le nto oyenzayo ayilunganga
b U-wrongo le nto oyenzayo u-wrongo ayilunganga
c Die ding wat jy doen is nie reg man

a This thing you are doing is not right

b You are wrong this thing you are doing you are wrong is not right

c The thing you are doing is not right man

Zuma supporters maintained that he was innocent of the charges brought against him and that he was unfairly targeted: 
a Wenzen' uZuma? Wen' ulawula wen' ulawul' amaskopiyoni awusitshel' ukuthi uZuma wenzeni?

b Wenzeni we-Ngcuka? Wen' ulawula wen' ulawul' amaskopiyoni kewuphendule ukuthi uZuma wenzeni?

a What has Zuma done? You (who) control the scorpions tell us what Zuma has done?

b What has he done, Ngcuka? You (who) control the scorpions answer what Zuma has done?

The women's rights group lamented the state of the nation, as they see so much violence against women and children:
a Isizwe siyaphela lyooo baba wami
b Baph' izingani zethu? lyooo baba wami
c Mfazi khawuleza lyooo baba wami

a The nation is dying Oh my father

b Where are our children? Oh my father

c Woman take a stand Oh my father

\section{Conclusion}

The strand that runs through most of the topics in the songs of the Zuma group could be labelled as populist. By 2005 ordinary citizens were so disenchanted with the Mbeki leadership that they were willing to turn a blind eye to the apparent faults of Zuma. This populist surge was expressed in minute detail in the songs of the people. It is clear that the unity of the pre-1994 populace gave way to unthinkable divisions. Preference was expressed for leftist political groupings, thus rejecting the centre. Abuse was heaped on a woman who dared to frustrate Zuma's rise to power by implicating the leader in rape; officials in law enforcement were ridiculed; women's rights groups were intimidated. In short, these performances staged a face-off between political, judicial, gender and other groupings. The country was confronted with some stark realities as the views of a leader on sex and HIV, as well as the acquiescent mentality of the populace on these issues, came to light. A commentator summarised the Zuma theatre as follows (Anon., 2006):

As the sordid details of Zuma's misdirected appetites unfolded in court, South Africans took up the issues raised in vibrant debate in the media and among themselves, testing attitudes 
on justice, gender, sexual politics, and political power in a cathartic babble that has left us enriched.

The performances of songs in front of the Supreme Court in Johannesburg also vividly illustrated the sustained vibrancy of performativity in South Africa. In the words of Schieffelin (1998:194):

Performances, whether ritual or dramatic, create and make present realities vivid enough to beguile, amuse or terrify. And through these presences, they alter moods, social relations, bodily dispositions and states of mind.

\section{Annexure A}

"It is also in the notion that one remains a good person in as much as his good deeds especially if they surpass what may be allegedly considered wrong doing even before proven guilty." (Cf. CD cover of Mthethwa et al., s.a.) Although the quote may make no sense in places, the convoluted language illustrates the emotional state of mind that was evident during the Zuma trial.

\section{List of references}

ANON. 2006. Editorial: No Zuma, not everyone is doing it. Sunday times: 38, 14 May.

GUNNER, L. 2008. Jacob Zuma, the social body and the unruly power of song. African affairs, 108(430):27-48.

HUGHES, G. 2006. Zuma "theatre" mocks law. The Star: 16 Mar.

HUGHES-FREELAND, F. 1998. Introduction. (In Hughes-Freeland, F., ed. Ritual, performance, media. London: Routledge. p. 1-28.)

MACALOON, J.J. 1984. Rite, drama, festival, spectacle: rehearsals towards a theory of cultural performance. Philadelphia: ISHI.

MTHETHWA, E., comp. s.a. "Akekho Ofana Nawe" on the CD 100\% JZ Halala!! Duckpound Music/Sony Music. [CD].

SAPA. 2006. Zuma supporters, media denounced by rights body. Saturday star: 2, 25 Mar.

SCHIEFFERLIN, E.L. 1998. Problemitizing performance. (In Hughes-Freeland, F., ed. Ritual, performance, media. London: Routledge. p. 194-207.)

SCHMIDT, M. 2005. Some call Zuma Mr. Delivery. Saturday star: 14, 12 Nov. 2005.

SHANGE, T. 2006. Zuma's the showman, while Mbeki's a shy man. The Star: 26, 19 Jun.

SMILLIE, S. 2006a. About 150 supporters show up at night vigil for "innocent" Msholozi. The Star: 4, 8 May.

SMILLIE, S. 2006b. Academics views differ on impact of Zuma's rape trial. The Star: 7 Jun.

WOOD, E.J. 2000. Forging democracy from below. Cambridge: Cambridge University Press.

ZOMA, I. 2005. Msholozi. Izingane Zoma Music. [CD]. 
ZUMA, J.G. 2006. Media statement. The Star: 10 May.

\section{Key concepts:}

divisions

morality

political songs

Zuma, Jacob

\section{Kernbegrippe:}

moraliteit

politieke liedjies

skeidslyne

Zuma, Jacob 